\title{
CHARAKTERYSTYKA TERENU BUDOWY W ASPEKCIE ZAGROŻEŃ BEZPIECZEŃSTWA PRACY
}

\begin{abstract}
Elementy systemu „człowiek - teren budowy" stwarzają okoliczności, które sprzyjają powstawaniu zagrożeń bezpieczeństwa w realizacji robót. Badania i analizy wskazują na decydujące znaczenie czynnika ludzkiego w zbiorze cech opisujących przyczyny wypadków w budownictwie. Teren budowy i jego elementy, wymieniane jako drugi, istotny element wpływający na zagrożenia, to coraz częściej podnoszone przedmioty badań bezpieczeństwa pracy w budownictwie. Niniejszy artykuł wpisuje się w nurt tych badań. Podjęto w nim próbę analizy cech terenu budowy (projektowych, realizacyjnych, środowiska) w celu wskazania ich znaczenia w definiowaniu okoliczności wypadku przy pracy. Badania zrealizowano na podstawie danych zarejestrowanych w statystycznych kartach wypadków, a dyskutowanymi jednostkami były zdarzenia wypadkowe przy pracy. Wykorzystując również źródła dodatkowe, w postaci tematycznych publikacji, utworzono zbiór warunków do zaistnienia przyczyn wypadków i scalono go ze zbiorem danych o wypadkach. W efekcie zestawiono grupę charakterystycznych zagrożeń na terenie budowy, które z kolei przypisano odpowiednim robotom budowlanym, sklasyfikowanym pod względem struktury technologiczno - organizacyjnej oraz zamodelowano czynniki determinujące zachowania pracowników budowlanych w czasie realizacji robót.
\end{abstract}

Słowa kluczowe: wypadek, przyczyny, pracownik, zachowanie

\section{Wprowadzenie}

Bezpieczeństwo pracy na terenie budowy jest niewątpliwie problemem złożonym. Wpływa na to specyfika budownictwa generująca grupę charakterystycznych zagrożeń, a także uwarunkowania organizacyjne, powodujące systematyczną zmienność frontu robót oraz rotację wykonawców. Nowoczesne technologie budowania powodują, iż czas trwania robót jest intensywnie skracany. Dąży się do możliwie najszybszego i najtańszego osiągnięcia założonego celu. Uwagę skupia się na minimalizacji kosztów, w tym poprzez minimalizację liczby zatrudnionych pracowników i nadzoru. Zjawisko bezpieczeństwa pracy

\footnotetext{
${ }^{1}$ Wojciech Drozd, Politechnika Krakowska, ul. Warszawska 24, 31-155 Kraków, tel. 1262821 25, wdrozd@ztob.pk.edu.pl
} 
w budownictwie wymaga więc uwzględnienia szerokiego kompleksu przyczyn powstawania zagrożeń wypadkowych.

W artykule podjęto próbę analizy cech terenu budowy i zachowań pracowników, celem wskazania ich znaczenia $w$ definiowaniu okoliczności wypadku przy pracy. Badania zrealizowano na podstawie danych zarejestrowanych w statystycznych kartach wypadków, a dyskutowanymi jednostkami były zdarzenia wypadkowe przy pracy.

\section{Identyfikacja zagrożeń}

Wypadki przy pracy, jako zdarzenia na terenie budów są następstwem przyczyn technicznych i organizacyjnych, powodowanych przede wszystkim błędami działalności ludzkiej. Są zdarzeniami losowymi, trudnymi lub niemożliwymi do przewidywania. Jednak możliwa jest identyfikacja zagrożeń bezpieczeństwa pracy [2]. Ich znajomość i opis okoliczności powstawania wypadków mogą wskazywać potencjalne środki na rzecz redukowania wypadków i ich skutków. Niezbędna do tego jest charakterystyka placu budowy. W tym celu utworzono grupy czynników, charakteryzujących plac budowy w aspekcie bezpieczeństwa pracy [3]. Przedstawiono je w formie schematu (Rys. 1).

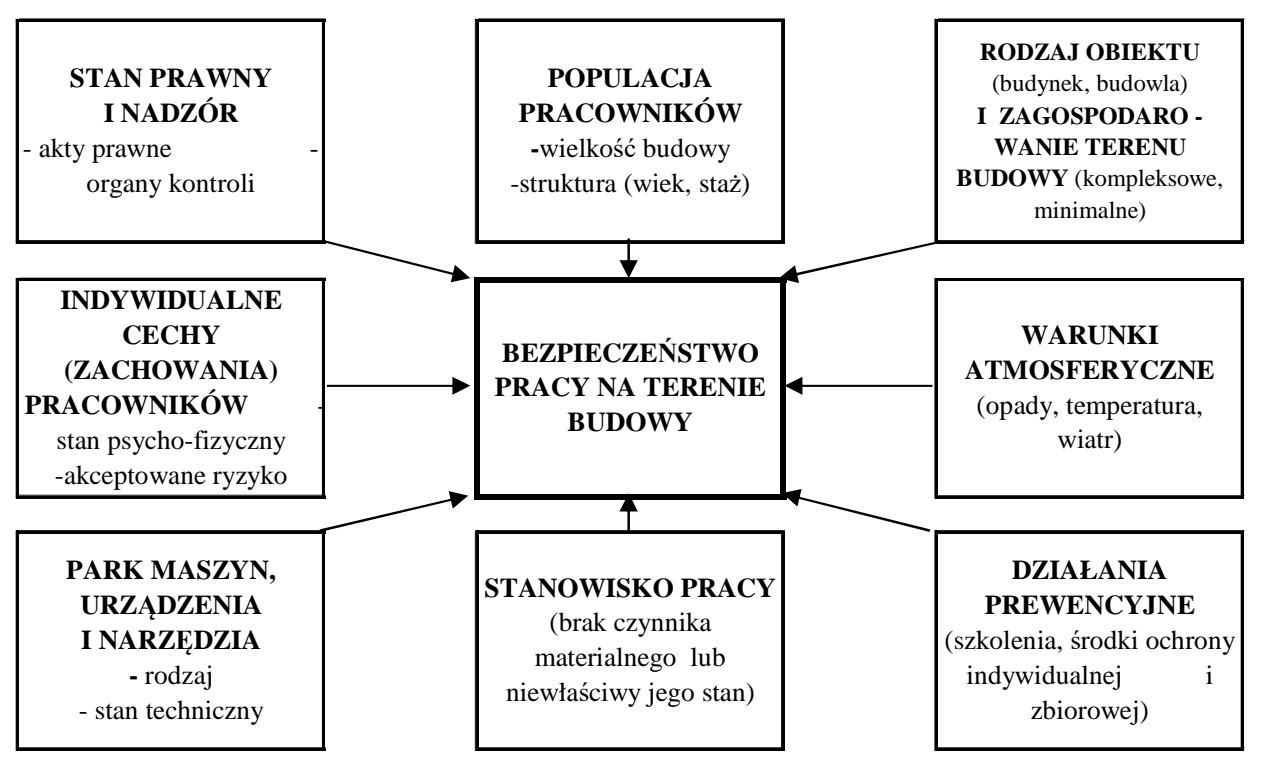

Rys. 1. Czynniki charakteryzujące teren budowy w aspekcie bezpieczeństwa pracy

Fig. 1. Factors characterizing the construction site in terms of safety

Dla zidentyfikowania zagrożeń wypadkowych analizie poddano informacje o wypadkach przy pracy na budowach Małopolski, zarejestrowane w statystycz- 
nych kartach wypadków, w 2015 roku. Na podstawie stwierdzonych braków i nieprawidłowości w aspekcie bhp, które bezpośrednio lub pośrednio przyczyniły się do zaistnienia wypadku, przyjęto strukturę rodzajową warunków do zaistnienia przyczyn wypadków. Warunki te związane są z czynnikami materialnymi (techniczne - maszyna, narzędzie lub inny przedmiot używany przez poszkodowanego), organizacją pracy oraz pracownikami. Ich udział w zaistniałych wypadkach, na budowach Małopolski, w 2015 roku, przedstawiono na Rys. 2.

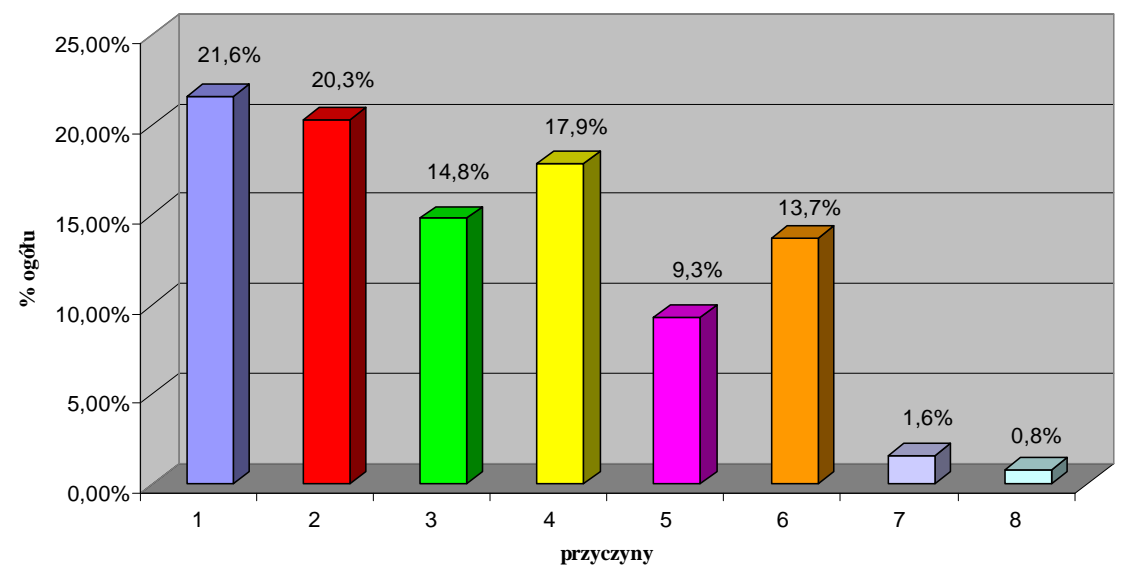

1 - niewłaściwy stan cz. materialnego

$\mathbf{3}$ - niewł. organizacja stanowiska pracy

5 - nie używanie sprzętu ochronnego

2 - niewłaściwa organizacja pracy

$\mathbf{4}$ - brak czynnika materialnego

6 - samowolne zachowanie się pracownika

7 - niewł. stan psycho-fizyczny pracownika

8 - inne

Rys.2. Warunki do zaistnienia przyczyn wypadków

Fig. 2. Conditions for the occurrence of accidents

Każdy wypadek był wydarzeniem spowodowanym najczęściej przez kilka przyczyn. Wyniki analizy dały możliwość określenia rodzaju kontaktu poszkodowanego z czynnikiem materialnym (źródłem), który wywołał wypadek. Określono grupę 18 charakterystycznych zagrożeń bezpieczeństwa pracy na terenie budowy. Zagrożenia i ich udział w zaistniałych wypadkach, na budowach Małopolski, w 2015 roku, przedstawiono na Rys. 3.

Potknięcie i poślizg, upadek do zagłębienia oraz upadek z wysokości, to najczęstsze przyczyny zaistnienia wypadku, natomiast niewłaściwy stan czynnika materialnego (technicznego) to najczęstsza okoliczność wywołująca przyczyny. 


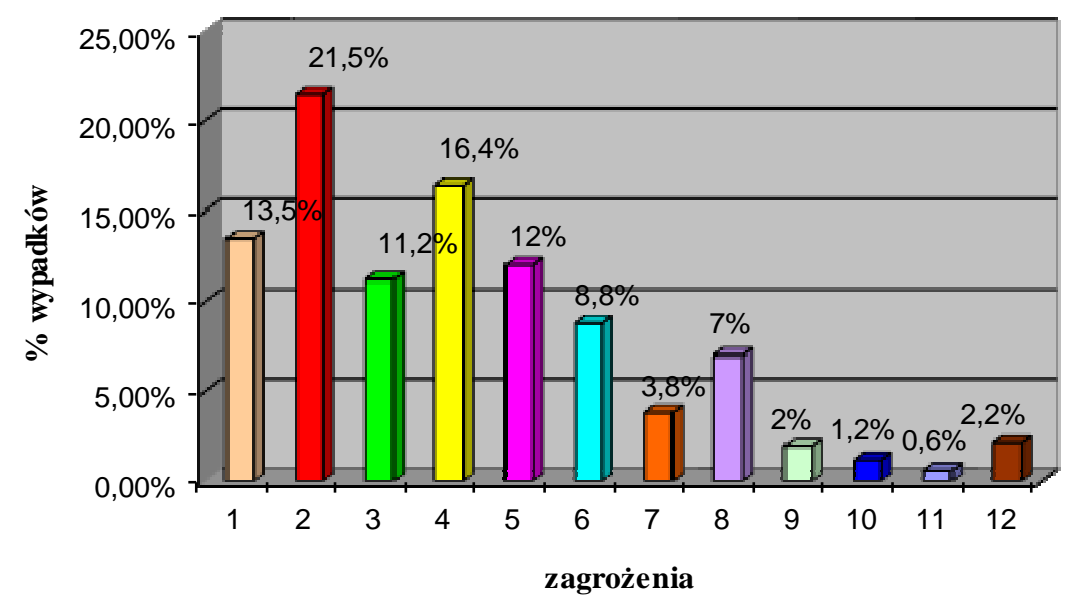

1 - upadek z wysokości

$\mathbf{3}$ - uderzenie przez spadające czynniki

5 - uderzenie o el. przemieszczane

7 - pochwycenie przez urządzenia

9 - przecięcia i skaleczenia

11 - przeciążenie przy dźwiganiu

2 - potknięcie i poślizg

4 - upadek do zagłębienia

6 - uderzenie o nieruchome czynniki

8 - porażenie prądem

10 - zgniecenie

12 - pozostałe

Rys. 3. Zagrożenia na terenie budowy

Fig. 3. Threats on the construction site

\section{Charakterystyka terenu budowy w strukturze technologicz- no-organizacyjnej}

Wyniki analizy pozwoliły przypisać grupę charakterystycznych zagrożeń na terenie budowy odpowiednim robotom budowlanym, sklasyfikowanym pod względem struktury technologiczno - organizacyjnej (Tablica 1).

\section{Czynniki determinujące działania pracowników}

Znajomość struktury rodzajowej wypadków i ich przyczyn jest niezbędna do identyfikacji czynników determinujących zachowania pracowników budowlanych w czasie realizacji robót, podczas których doszło do niepożądanych zdarzeń $[4,5,7]$. Szczegółowa analiza danych na temat zdarzeń wypadkowych, zarejestrowanych w statystycznych kartach wypadków przy pracy, dała możliwość utworzenia modelu zachowań pracownika budowlanego podczas realizacji robót, możliwego do wykorzystania w procesie efektywnego zarządzania bez- 
Tablica 1. Roboty budowlane wraz z charakterystycznymi zagrożeniami

Table 1. Works with characteristic threats

\begin{tabular}{|c|c|c|}
\hline Lp. & Rodzaj robót & Zagrożenia \\
\hline 1 & $\begin{array}{l}\text { Zagospodarowanie terenu } \\
\text { budowy }\end{array}$ & $\begin{array}{l}\text { potknięcie i poślizg, zgniecenie, przeciążenie przy dźwiganiu, } \\
\text { przecięcia i skaleczenia, nagły przy padek medy czny, uderzenie } \\
\text { o elementy przemieszczane lub będące w ruchu, porażenie } \\
\text { prądem. }\end{array}$ \\
\hline 2 & Roboty ziemne & $\begin{array}{l}\text { upadek do zagłębienia, zasypanie w wykopie, porażenie } \\
\text { prądem, uderzenie o elementy przemieszczane lub będące } \\
\text { w ruchu, pochwy cenie przez urządzenia. }\end{array}$ \\
\hline 3 & Roboty betonowe & $\begin{array}{l}\text { porażenie prądem, porażenie światłem, pochwy cenie przez } \\
\text { urządzenia, uderzenie o elementy przemieszczane lub będące } \\
\text { w ruchu, uderzenie o nieruchome czy nniki, awarie, przecięcia } \\
\text { i skaleczenia, upadek z wy sokości. }\end{array}$ \\
\hline 4 & Roboty murowe & $\begin{array}{l}\text { upadek z wy sokości, przecięcia i skaleczenia, uderzenie przez } \\
\text { spadające czy nniki. }\end{array}$ \\
\hline 5 & $\begin{array}{l}\text { Konstrukcje drewniane } \\
\text { i pokry cia dachowe }\end{array}$ & $\begin{array}{l}\text { upadek z wy sokości, przeciążenie przy dźwiganiu, przecięcia } \\
\text { i skaleczenia, nagły przy padek medyczny. }\end{array}$ \\
\hline 6 & Roboty izolacyjne & $\begin{array}{l}\text { upadek z wy sokości, uderzenie przez spadające czynniki, } \\
\text { substancje chemiczne, przecięcia i skaleczenia, porażenie } \\
\text { termiczne. }\end{array}$ \\
\hline 7 & $\begin{array}{l}\text { Roboty impregnacyjne } \\
\text { i odgrzy bieniowe }\end{array}$ & $\begin{array}{l}\text { przecięcia i skaleczenia, nagły przy padek medy czny, porażenie } \\
\text { termiczne, substancje chemiczne. }\end{array}$ \\
\hline 8 & Roboty montażowe & $\begin{array}{l}\text { uderzenie przez spadające czynniki, hałas, uderzenie } \\
\text { o nieruchome czy nniki, porażenie światłem. }\end{array}$ \\
\hline 9 & Roboty wykończeniowe & $\begin{array}{l}\text { upadek z wy sokości, przeciążenie przy dźwiganiu, potknięcie } \\
\text { i poślizg, uderzenie przez spadające czynniki, substancje } \\
\text { chemiczne. }\end{array}$ \\
\hline 10 & Roboty rozbiórkowe & $\begin{array}{l}\text { upadek z wy sokości, uderzenie przez spadające czy nniki, } \\
\text { zgniecenie, uderzenie o elementy przemieszczane lub będące } \\
\text { w ruchu, hałas, porażenie termiczne, substancje chemiczne. }\end{array}$ \\
\hline
\end{tabular}

pieczeństwem pracy. Model prezentuje zarówno cechy osobowe, jak i cechy terenu budowy. Cechy te ujęto w sposób połączony. W modelu tym główną rolę w kształtowaniu zachowania przypisano motywacjom pracownika, związanym z czynnikami osobowymi. Powiązanie z cechami terenu budowy następuje na poziomie percepcji zagrożeń (Rys. 4.). 


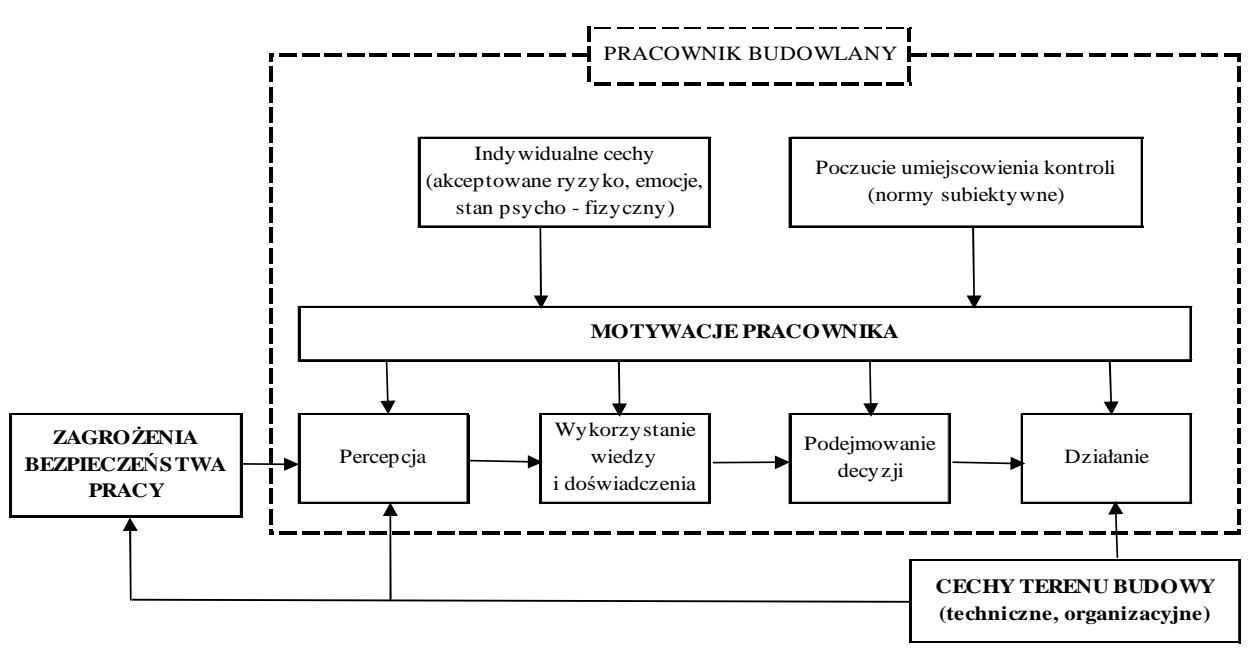

Rys. 4. Model zachowań pracownika budowlanego podczas realizacji robót

Fig. 4. Model of behavior of a construction worker during the execution of works

$\mathrm{Z}$ przedstawionego schematu modelu zachowania pracownika budowlanego wynika, że na wybór jego działania wpływają czynniki związane z sumą: odbioru bodźców zewnętrznych, cech indywidualnych (z towarzyszącymi emocjami) oraz subiektywnych norm zachowania i własnej kontroli.

Zwrócenie uwagi na istotę czynników osobowych przy opisie bezpieczeństwa pracy na terenie budowy znajduje uzasadnienie w wynikach analiz statystycznych kart wypadku. Zauważono, że największą grupę osób poszkodowanych w wypadkach budowlanych, w województwie małopolskim, w 2015 r., stanowiły osoby w wieku 40 - 44 lata oraz osoby ze stażem pracy do 1 roku lub powyżej 16 lat na zajmowanym stanowisku pracy. Związek wieku i stażu pracy ze zdarzeniami wypadkowymi wiąże się z organizacją stanowiska pracy, akceptowanym ryzykiem, i stanem psycho - fizycznym poszkodowanych.

Rola percepcji cech terenu budowy w podejmowaniu decyzji widoczna jest głównie w rodzaju obiektu budowlanego, elementach zagospodarowania terenu budowy, środkach prewencyjnych oraz parku sprzętu budowlanego i stanowi przedmiot dalszych badań autora, w rzeczonej problematyce.

\section{Podsumowanie}

W analizie statystycznych kart wypadków i tworzeniu charakterystyki terenu budowy uwzględniono klasyfikację robót szczególnie niebezpiecznych, ze względu na wysokość lub głębokość ich prowadzenia, dla której zgodnie z Rozporządzeniem Ministra Infrastruktury, z dnia 6 lutego 2003 roku, wymiar $1 \mathrm{~m}$ stanowi granicę. 
Wyniki badań oraz studium literatury z zakresu wpływu cech terenu budowy na bezpieczeństwo robót i identyfikacji czynników determinujących zachowanie pracownika budowlanego $[1,6,8,9]$, pozwalają sformułować następujące wnioski:

- wypadki przy pracy jako zdarzenia na placu budowy są następstwem przyczyn technicznych i organizacyjnych powodowanych przede wszystkim błędami działalności ludzkiej,

- każdy wypadek jest wydarzeniem spowodowanym najczęściej przez kilka przyczyn,

- wypadki są zdarzeniami losowymi, trudnymi lub niemożliwymi do przewidywania. Możliwa jest identyfikacja zagrożeń bezpieczeństwa pracy,

- w identyfikacji czynników determinujących bezpieczeństwo pracy na terenie budowy celowe jest koncentrować się na stanowiskach pracy oraz indywidualnych cechach (zachowaniu) pracowników,

- wyniki analizy wypadków przy pracy dały możliwość określenia rodzaju kontaktu poszkodowanego z czynnikiem materialnym (źródłem), który wywołał wypadek. Istnieje grupa charakterystycznych zagrożeń, najsilniej powiązanych $\mathrm{z}$ wypadkami w różnych robotach budowlanych. Zawarte w nich informacje mogą być wykorzystywane przy każdym projektowaniu i wdrażaniu środków poprawy warunków bezpieczeństwa pracy,

- znajomość zagrożeń i opis okoliczności powstawania wypadków mogą wskazywać potencjalne środki na rzecz redukowania wypadków i ich skutków,

- znajomość struktury rodzajowej wypadków i ich przyczyn oraz model zachowań pracownika budowlanego podczas realizacji robót, mogą być wykorzystywane do efektywnego zarządzania bezpieczeństwem pracy.

Zawarte $\mathrm{w}$ artykule wyniki badań i analiz nie wyczerpują problemu bezpieczeństwa pracy na terenie budowy. Część rozpoczętych wątków badawczych potwierdza potrzebę i kierunki dalszych prac. Wątpliwości, jakie powstały przy analizie danych nakłaniają do podjęcia dalszych badań, w tym pozostałych czynników kształtujących poziom bezpieczeństwa pracy na terenie budowy (rodzaj obiektu budowlanego, zagospodarowanie placu budowy, warunki atmosferyczne, nadzór) i wskazania działań zmierzających do poprawy warunków bezpieczeństwa pracy na budowach.

\section{Literatura}

[1] Behm M.:Construction sector. Journal of Safety Research, Vol. 39, No. 2, 2008, pp. $175-178$.

[2] Drozd W., Kowalik M.:Nowoczesne systemy zabezpieczeń bhp przy robotach na wysokości. Czasopismo techniczne, Kraków 26 - 28 czerwca 2014, str. 247 - 255.

[3] Drozd W. Regresion analysis of accident absenteeism and variables describing working conditions. Monografia 480 - Recent advances in civil engineering: Construction management - Inżynieria Lądowa, Politechnika Krakowska 2015. 
[4] Hoła B.: Modelowanie jakościowe i ilościowe wypadkowości w budownictwie. Wrocław : Oficyna Wydawnicza Politechniki Wrocławskiej, 2008.

[5] Hoła B., Szóstak M.: Model rozwoju sytuacji wypadkowej w budownictwie. Czasopismo techniczne - Budownictwo. Politechnika Krakowska 2014.

[6] Kiviniemi M., Sulankivi K.: BIM - based Safety Management and Communication for Building Construction. Copyright (C) VTT 2011.

[7] Pęciłło M.: Identyfikacja i modelowanie procesów zarządzania bezpieczeństwem i higieną pracy w przedsiębiorstwie. Bezpieczeństwo Pracy - Nauka i Praktyka, 2003.

[8] Rozenfeld O., Sacks R.: Construction job safety analysis. Safety Science 48, 2010, pp. $491-498$.

[9] Stępień T.: Identyfikacja czynników determinujących wypadkowość w budownictwie. Czasopismo techniczne - Budownictwo. Politechnika Krakowska 2014.

\title{
CHARACTERISTICS OF CONSTRUCTION SITE IN TERMS OF OC- CUPATIONAL SAFETY
}

\begin{abstract}
S u m m a r y
Elements of the system "man - construction site" create the circumstances that favor the formation of security risks in the execution of works. Research and analysis show the crucial importance of the human factor in a set of attributes describing the causes of accidents in the construction industry. The construction site and its components, listed as the second important element influencing the threat is increasingly raised subjects of research work safety in construction. This article is a part of a trend in these studies. It studies have been taken to analyze the characteristics of the construction site (design, execution, environment) and to indicate their importance in defining the circumstances of the accident at work. The research was carried out on the basis of data recorded in the statistics documents of accidents, and the units were debated event of accidents at work. Using the additional sources, such as thematic publications, set of conditions for the occurrence of accidents was created and merge with a set of data on accidents. As the result, the list of specific hazard combined with the relevant construction works and modeled the behavior of a construction worker during the execution of works.
\end{abstract}

Keywords: accident, causes, worker, behavior

Przestano do redakcji: 07.06.2016 $r$.

Przyjęto do druku: 30.06.2016 r.

DOI: $10.7862 / r b .2016 .19$ 